\title{
Utilization of hydrolyzed corncob as a carbohydrate source in diets for red Nile tilapia Oreochromis niloticus
}

\section{Pemanfaatan hasil hidrolisis tongkol jagung sebagai sumber karbohidrat dalam pakan ikan nila merah Oreochromis niloticus}

\author{
Fauzan $^{1}$, Muhammad Agus Suprayudi ${ }^{*}$, Ichsan Achmad Fauzi ${ }^{1}$, Julie Ekasari ${ }^{1}$ \\ 'Department of Aquaculture, Faculty of Fisheries and Marine Sciences, \\ IPB University, Bogor, West Java, Indonesia 16680 \\ *Corresponding author: muhammadsu@ apps.ipb.ac.id
}

(Received July 26, 2021; Accepted January 19, 2022)

\begin{abstract}
This study was aimed to evaluate the influence of corncob hydrolysis on its crude fiber content, digestibility level, and utilization in the red Nile tilapia diet. This study was performed in two steps, namely hydrolysis and digestibility test. The first study step was enzymatic hydrolysis using $0.4 \mathrm{~g} / \mathrm{kg}$ cocktail enzyme, followed by chemical hydrolysis using hydrochloric acid $(\mathrm{HCl})$ at different treatments, i.e. concentration, incubation period, and ratio. The second step was designed using a completely randomized design with five treatments, i.e. Rd (reference diet), TJt15\% (15\% unhydrolyzed corncob), TJt30\% (30\% unhydrolyzed corncob), TJh15\% (15\% corncob hydrolysis), and TJh30\% (30\% corncob hydrolysis). The average weight of tilapia was $15.86 \pm 0.19 \mathrm{~g} / \mathrm{fish}$. The hydrolyzed corncob meal used for the second study step from the hydrolysis production could reduce $57.53 \%$ of crude fiber, $38.15 \%$ of NDF fiber fraction, $6.43 \%$ of ADF fiber fraction, and $61.96 \%$ of hemicellulose. The digestibility test results showed that the hydrolyzed corn cob diet obtained a higher digestibility level, digestive enzyme activity, and blood plasma protein than the unhydrolyzed corncob diet $(\mathrm{P}<0.05)$. This study concludes that the corncob hydrolysis eliminates the crude fiber content, fiber fraction contents (NDF, ADF, and hemicellulose), and improves the digestibility level of red Nile tilapia.
\end{abstract}

Keywords: Corn cobs, crude fiber, digestibility, hydrolysis, tilapia.

\begin{abstract}
ABSTRAK
Penelitian ini bertujuan mengevaluasi pengaruh hidrolisis tongkol jagung terhadap kandungan serat kasar, kecernaan, dan pemanfaatannya dalam pakan ikan nila merah. Penelitian dilakukan dalam dua tahap, yaitu hidrolisis bahan dan uji kecernaan. Penelitian tahap pertama yaitu hidrolisis secara enzimatik menggunakan koktail enzim $0,4 \mathrm{~g} / \mathrm{kg}$ dan dilanjutkan dengan hidrolisis kimiawi menggunakan asam klorida $(\mathrm{HCl})$ dengan perlakuan yang berbeda yaitu konsentrasi, lama waktu inkubasi, dan rasio. Penelitian tahap kedua dirancang dengan menggunakan rancangan acak lengkap dengan lima perlakuan yaitu Rd, TJt15\% (tongkol jagung tidak dihidrolisis 15\%), TJt30\% (tongkol jagung tidak dihidrolisis 30\%), TJh15\% (tongkol jagung dihidrolisis 15\%), dan TJh30\% (tongkol jagung

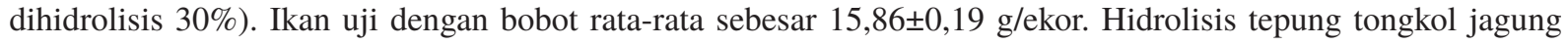
dengan konsentrasi $\mathrm{HCl} 0.1 \mathrm{~N}$, lama waktu inkubasi 8 jam, dan dengan rasio 1:4 yang digunakan untuk penelitian selanjutnya. Hidrolisis terhadap tepung tongkol jagung dapat menurunkan serat kasar 57,53\%, fraksi serat NDF $38,15 \%$, ADF 6,43\%, dan hemiselulosa 61,96\%. Hasil penelitian uji kecernaan menunjukkan bahwan pakan yang mengandung tongkol jagung terhidrolisis menghasilkan nilai kecernaan, aktivitas enzim pencernaan dan protein plasma darah yang lebih tinggi dibandingkan dengan yang tidak dihidrolisis $(\mathrm{P}<0.05)$. Kesimpulanya, hidrolisis tongkol jagung menggunakan asam klorida $(\mathrm{HCl}) 0,1 \mathrm{~N}$, lama waktu inkubasi 8 jam, dan rasio 1:4 dapat menurunkan serat kasar, fraksi serat (NDF, ADF, dan hemiselulosa), serta meningkatkan nilai kecernaan pakan ikan nila merah.
\end{abstract}

Kata kunci : Hidrolisis, kecernaan, nila, serat kasar, tongkol jagung 


\section{INTRODUCTION}

Feed is an input component in fish culture for fish livelihood, growth, and reproduction (Amarwati et al., 2015; Haidar et al., 2016). One of macronutrient components found in feed is carbohydrates. Carbohydrates are functioned as a non-protein energy source (protein-sparing effect) mainly used in freshwater fish feed at $30-47 \%$ (Kamalam et al., 2017; Coutinho et al., 2018). In general, most fish feed use imported materials (Suprayudi, 2017). Carbohydrates used in aquaculture can be obtained from plant materials, such as wheat and their derivatives (Muliani et al., 2019; Amin et al., 2020). To reduce the imported material dependence, a qualified local alternative material development from by-product materials is required with cheaper price.

Carbohydrate sources used in aquaculture feed is originated from plant materials, such as wheat and their derivatives (Suprayudi, 2017). One of the potentially-developed local carbohydrate sources is the corncob. Corncob is a by-product material from the corn culture. However, the corncob has not yet been utilized well (Kanegoni et al., 2015). Corncob has $3.42 \%$ protein, $9.55 \%$ lipid, $4.41 \%$ ash, and $74.51 \%$ carbohydrate (Olagunju et al., 2013). A study has been performed to utilize the corncob utilization for Nile tilapia, Java barb, and catfish (Rostika \& Safitri, 2012; Klahan et al., 2016).

Although studies regarding the corncob utilization in feed ingredient has been performed on fish culture, there are several obstacles found, one othe $\mathrm{f}$ which is high crude fiber level in the corncob. Corncob contains 32.6 - 54.48\% crude fiber (Widaningsih et al., 2018), composed of $29.35 \%$ neutral detergent fiber, $36.3 \%$ acid detergent fiber, $3133 \%$ hemicellulose, $4044 \%$ cellulose, and $1618 \%$ lignin (Pointner et al., 2014). Crude fiber is one of the antinutrient materials that affect on feed digestibility (Enami, 2011). To optimize the corncob utilization as a fish feed ingredient requires further manipulation to reduce the crude fiber level, namely through a hydrolysis approach.

Based on several studies related to hydrolysis on various plant material ingredients, the hydrolysis method is considered effective to degrade crude fiber and improve the nutrient level. The use of rumen fluid can reduce the crude fiber level from $14.34 \%$ to $6.98 \%$ and improve the fish diet nutrient level (Jusadi et al., 2013; Zuraida $e t$ al., 2013). Suprayudi et al. (2016) also reported that $400 \mathrm{~mL} / \mathrm{kg}$ rubber seed feed ingredient could increase the digestibility level and replace the plant protein source up to $50 \%$. This condition occurred as rumen liquid was an enzyme that could hydrolyze the feed ingredient (Suprayudi et al., 2014). However, the use of rumen liquid has a drawback due to discontinued and commercial availability, followed by special handling to preserve its quality, which needs other materials such as enzyme cocktails. Anugrah (2018) stated that the use of $0.4 \mathrm{~g} / \mathrm{kg}$ enzyme cocktail was more effective to hydrolyze crude fiber than $200 \mathrm{~mL} / \mathrm{kg}$ sheep rumen liquid. Crude fiber can be hydrolyzed enzymatically through chemical substances. An example of chemical substance that can be used as hydrolysis material is hydrochloric acid $(\mathrm{HCl})$.

Another study result mentioned that the $0.1 \mathrm{~N}$ $\mathrm{HCl}$ could improve the glucose level in cassava skin flour (Mastuti \& Setyawardhani, 2010). Based on the following explanations, an enzymatic and acidic hydrolysis experiment is required to reduce the crude fiber level and improve the digestibility level as a diet ingredient for Nile tilapia. This study was aimed to evaluate the hydrolysis effect of corncob on the crude fiber level, digestibility level, and its utilization in the red Nile tilapia $(O$. niloticus) diet.

\section{MATERIALS AND METHODS}

This study was divided in two steps, namely corncob meal hydrolysis and digestibility test.

\section{First step: Corncob meal hydrolysis}

Corncob as the agriculture by-product was obtained from Mbawa Village, Bima District, Nusa Tenggara Barat. The corncobs were dried until reaching $9-10 \%$ moisture level, then the corncobs were ground sieved with a 75- $\mu \mathrm{m}$ sieve (mesh 200) until appropriate size. Furthermore, the corncob meal was mixed with an enzyme cocktail at $0.4 \mathrm{~g} / \mathrm{kg}$ dose diluted using destilled water at $30 \%$ of the material weight, then the material was homogenized and preserved in a plastic container for a 24-hour incubation period (Anugrah 2018). Next, the corncob meal was hydrolyzed with $0.1 \mathrm{~N}$ and $0.2 \mathrm{~N}$ hydrochloric acid $(\mathrm{HCl})$ at 1:2, 1:4, and 1:6 ratio, each of which was soaked with $\mathrm{HCl}$ for $0,4,8,12$, and 24 hours. To identify the crude fiber degradation level, a sample was taken every 4 hours for crude fiber content analysis. The measurement of each sample was repeated twice. Treatments that showed the highest crude fiber content were used 
as the basic hydrolysis standard of the fish diet ingredient for the digestibility test step.

\section{Second step: Digestibility test}

The second step in this study was a digestibility test. Materials tested contained unhydrolyzed and hydrolyzed corncob meal. In this test, the diet was added with $0.6 \%$ chromium oxide $\left(\mathrm{Cr}_{2} \mathrm{O}_{3}\right)$ as a digestibility marker (Watanabe, 1988).

The second step study was designed using a completely randomized design with five treatments and four replications. The treatments were preference diet without corncob addition (Rd), 15\% unhydrolyzed corncob meal (TJt15\%), $30 \%$ unhydrolyzed corncob meal (TJt30\%), $15 \%$ hydrolyzed corncob meal (TJh15\%), and $30 \%$ hydrolyzed corncob meal (TJh30\%). The diet composition for the digestibility test and its proximate analysis is presented in Table 1.

\section{Feces maintenance and collection}

The fish samples were red Nile tilapia obtained from the experimental pond of Department of Aquaculture, IPB University, which had an average weight of $15.86 \pm 0.19 \mathrm{~g} /$ fish and were acclimatized for 7 days. A day before weighing, the fish were fasted. Fsh were stocked at 15 fish/container. The containers were aquaria at $100 \times 40 \times 50 \mathrm{~cm}^{3}$ size and $35 \mathrm{~cm}$ water height.
After the adaptation, fish were fed in apparent satiation three times a day at 07.00, 13.00, and 17.00 GMT+7. Feces samples were collected using syphonized hose and accommodated in a container equipped with filter. The syphon debit was maintained carefully until all collected feces remained solid. Fish feces were started to collect on 4 days after feeding as taken on an hour after feeding activity. These feces were collected in sample bottles and preserved in a freezer to avoid degradation. After the feces were collected for further analysis, feces were heated in an oven for $8-10$ hours at $50^{\circ} \mathrm{C}$ and analyzed the nutrient contents (protein, lipid, and NFE). For $\mathrm{Cr}_{2} \mathrm{O}_{3}$ measurement, a spectrophotometer was used at $350 \mathrm{~nm}$ wavelength.

At the end of the experiment, digestive enzyme activity, glucose, and plasma protein were measured. The measured digestive enzymes were amylase, lipase, and protease. Sample for enzyme activity analysis was a fish digestive tract, namely intestine. The sample was separated from the cleaned fish body and collected in a sample plastic container, before preserving in a freezer at $-20^{\circ} \mathrm{C}$ (Borlongan, 1990). For blood samples, 2-3 fish were taken from each replication container unit for blood glucose analysis. The blood samples were obtained from the caudal vein using a $1.5 \mathrm{~mL}$ syringe rinsed with a $3.8 \%$ natrium

Table 1. Diet composition for digestibility test of corncob (\% dryweight)

\begin{tabular}{|c|c|c|c|c|c|}
\hline \multirow{2}{*}{ Diet composition } & \multicolumn{5}{|c|}{ Treatment } \\
\hline & $\mathrm{Rd}$ & TJt15\% & TJt30\% & TJh15\% & TJh30\% \\
\hline Commercial diet & 99.2 & 84.2 & 69.2 & 84.2 & 69.2 \\
\hline Unhydrolyzed corncob & - & 15 & 30 & - & - \\
\hline Hydrolyzed corncob & - & - & - & 15 & 30 \\
\hline PMC & 0.2 & 0.2 & 0.2 & 0.2 & 0.2 \\
\hline $\mathrm{Cr}_{2} \mathrm{O}_{3}$ & 0.6 & 0.6 & 0.6 & 0.6 & 0.6 \\
\hline Total & 100 & 100 & 100 & 100 & 100 \\
\hline \multicolumn{6}{|l|}{ Proximate (\% dryweight) } \\
\hline Protein & 30.92 & 25.62 & 24.58 & 28.16 & 26.27 \\
\hline Lipid & 7.45 & 6.41 & 5.46 & 6.10 & 5.11 \\
\hline Ash & 12.22 & 11.45 & 14.96 & 10.26 & 9.082 \\
\hline Crude fiber & 3.46 & 9.17 & 12.85 & 4.70 & 9.14 \\
\hline NFE & 38.98 & 40.87 & 37.08 & 44.08 & 43.87 \\
\hline $\mathrm{GE}(\mathrm{kcal} / 100 \mathrm{~g})$ & 403.00 & 371.47 & 341.00 & 395.76 & 375.01 \\
\hline $\mathrm{C} / \mathrm{P}$ & 13.03 & 14.50 & 13.87 & 14.05 & 14.28 \\
\hline
\end{tabular}

Note: $\mathrm{Rd}=$ Reference diet; TJt = Unhydrolyzed corncob; TJh = hydrolyzed corncob; PMC = Polymethylolcarbamide; $\mathrm{NFE}=$ Nitrogen-free extract; GE $=$ gross energy, $1 \mathrm{~g}$ protein $=5.6 \mathrm{kcal}$; lipid $=9.4 \mathrm{kcal}$; carbohydrate $=4.1 \mathrm{kcal}$; $\mathrm{C} / \mathrm{P}=$ Energy per protein ratio (Watanabe, 1988). 
citrate as an anticoagulant. Blood samples were taken at $1 \mathrm{~mL}$ and collected in $1.5 \mathrm{~mL}$ microtubes and centrifuged for 10 minutes at $3000 \mathrm{rpm}$. The separated blood plasma was taken using a pipette and moved to the tube. During the maintenance period, the water quality was in an optimum range, as the average temperature was $30.68^{\circ} \mathrm{C}$, while the dissolved oxygen level was $3.46 \mathrm{mg} / \mathrm{L}$

\section{Parameters}

Parameters observed in the second step were specific growth rate, digestibility, digestive enzyme activity, blood glucose, and blood plasma protein. The total, nutrient, energy, and ingredient digestibility levels were calculated using the following formulas (Watanabe, 1988):

$$
\begin{gathered}
\text { Total digestibility }(\%)=1-\frac{\% \mathrm{Cr}_{2} \mathrm{O}_{3} \text { in Diet }}{\% \mathrm{Cr}_{2} \mathrm{O}_{3} \text { in Feces }} \times 100 \\
\text { Nutrient digestibility }(\%)= \\
1-\left(\frac{\% \mathrm{Cr}_{2} \mathrm{O}_{3} \text { in Diet }}{\% \text { Nutrient in Diet }} \times \frac{\% \text { Nutrient in feces }}{\% \mathrm{Cr}_{2} \mathrm{O}_{3} \text { in feces }}\right) \times 100 \\
\text { Ingredient digestibility }(\%)=\frac{\mathrm{ADT}-0.7 \mathrm{AD}}{0.3}
\end{gathered}
$$

Note:

ADT $=$ Test diet digestibility value

$\mathrm{AD}=$ Reference diet digestibility value

$$
\text { Energy digestibility }(\%)=\frac{\mathrm{EDT}-0.7 \mathrm{ED}}{0.3}
$$

Note:

EDT $=$ Test diet digested energy

ED $\quad=$ Reference diet digested energy

\section{Chemical analysis}

The corncob was analyzed at the beginning and end of the study to determine the fiber fraction degradation percentage (AOAC 2012). The fiber fraction parameters were NDF, ADF, and hemicellulose contents. The amylase, protease, and lipase enzyme activity levels were performed using Borlongan (1990) method. The blood plasma protein and blood glucose parameters were measured using Bradford and ortho-toluidine reagents (Dubowski, 2008).

The blood samples were centrifuged at 3000 rpm speed for 15 minutes to obtain the blood plasma, before adding the $5 \mathrm{~mL}$ Bradford reagent and preserved in a freezer, then vortexed and incubated for 10-60 minutes at room temperature. The plasma protein sample solution absorbance was read using a spectrophotometer at $595 \mathrm{~nm}$ wavelength. To identify the blood glucose level, the cold blood plasma was analyzed using a spectrophotometer at $\lambda=530 \mathrm{~nm}$.

\section{Data analysis}

The measurement result data during the study were analyzed using the analysis of variance (ANOVA) with Microsoft Excel and SPSS 20.0. If the ANOVA test results were significantly different, a further test was performed using Duncan's test at $95 \%$ degree of confidence.

\section{RESULTS AND DISCUSSIONS}

\section{Results}

The results of the first step showed that different concentration, incubation period, and ratio produced different crude fiber degradation levels of corncob meal (Table 2). The highest degradation level occurred in the $0.1 \mathrm{~N}$ concentration with an 8-hour incubation period and 1:4 ratio. Therefore, this treatment was then used as an optimum treatment for the digestibility test.

The influence of hydrolysis treatment with 0.1 $\mathrm{N} \mathrm{HCl}, 8$-hour incubation, and 1:4 ratio on the

Table 2. The crude fiber content of corncob hydrolyzed with hydrochloric acid with different concentration, incubation period, and ratio (material and solution) (\% dryweight).

\begin{tabular}{ccccccc}
\hline \multirow{2}{*}{ Concentration } & Ratio & \multicolumn{5}{c}{ Incubation period (hour) } \\
\cline { 3 - 7 } & $1: 2$ & 23.63 & 21.85 & 18.50 & 23.27 & 23.35 \\
\hline \multirow{3}{*}{$0.1 \mathrm{~N}$} & $1: 4$ & 22.23 & 16.63 & 14.53 & 23.95 & 22.77 \\
& $1: 6$ & 22.18 & 21.83 & 17.55 & 14.73 & 21.64 \\
& $1: 2$ & 22.06 & 19.60 & 21.69 & 14.60 & 20.99 \\
$0.2 \mathrm{~N}$ & $1: 4$ & 20.68 & 16.19 & 16.25 & 20.40 & 26.40 \\
& $1: 6$ & 23.72 & 21.38 & 15.45 & 18.44 & 17.10 \\
\hline
\end{tabular}


nutrient contents of corncob is presented in Table 3. Hydrochloric acid hydrolysis had a significant difference on a corncob nutrient level $(\mathrm{P}<0.05)$. The nutrient content analysis results showed decreased lipid, ash, and crude fiber contents at $75.5 \%, 36.9 \%$, and $57.5 \%$, respectively, while the protein and NFE contents increased at $22.2 \%$ and $34.8 \%$, respectively.

Table 3. Nutrient composition of corncob meal before and after the $\mathrm{HCl}$ hydrolysis (\% dryweight)

\begin{tabular}{ccc}
\hline Composition $(\%)$ & TJt & TJh \\
\hline Protein & 4.37 & 5.62 \\
Lipid & 3.02 & 0.74 \\
Ash & 5.93 & 3.74 \\
NFE & 42.28 & 55.89 \\
Crude fiber & 34.22 & 14.53 \\
\hline
\end{tabular}

The study results of hydrolyzed corncob with $0.1 \mathrm{~N} \mathrm{HCl}$, 8-hour incubation, and 1:4 ratio significantly influenced the crude fiber fraction content. The crude fiber fraction analysis showed a significantly different $(\mathrm{P}<0.05)$ between unhydrolyzed and hydrolyzed corncobs. Decreased NDF, ADF, and hemicellulose fiber fractions after the hydrolysis process was obtained at $38.15 \%, 6.45 \%$, and $61.92 \%$, respectively (Table 4).

Table 4. The unhydrolyzed and hydrolyzed corncob crude fiber fraction profiles with $0.1 \mathrm{~N} \mathrm{HCl}, 8$-hour incubation, and 1:4 ratio

\begin{tabular}{ccc}
\hline Crude fiber fraction & TJt & TJh \\
\hline NDF & $88.86 \pm 3.73^{\mathrm{b}}$ & $54.96 \pm 2.48^{\mathrm{a}}$ \\
ADF & $38.10 \pm 1.41^{\mathrm{b}}$ & $35.56 \pm 083^{\mathrm{a}}$ \\
Hemicelullose & $50.76 \pm 5.14^{\mathrm{b}}$ & $19.33 \pm 2.18^{\mathrm{a}}$
\end{tabular}

Note: TJt $=$ Unhydrolyzed corncob; TJh $=$ Hydrolyzed corncob. Different superscript letters after average \pm standard deviation values show a significant difference $(\mathrm{P}<0.05)$.
The digestibility test results on the diet ingredient performed in the second step showed signifinicant increased digestibility values (total, nutrient, energy, and ingredient) $(\mathrm{P}<0.05)$. The TJt30\% treatment had lower total and carbohydrate digestibility values than the $\mathrm{TJt} 15 \%$, TJh15\%, and TJh30\% treatments. The protein and lipid digestibility values on the unhydrolyzed corncob diets, namely $\mathrm{TJ} 15 \%$ and $\mathrm{TJ} 30 \%$ obtained an insignificant different value, but showing a significant different value on the TJh $15 \%$ and $\mathrm{TJh} 30 \%$ treatments. The highest protein digestibility was obtained from the TJh $15 \%$ treatment. Meanwhile, the highest lipid digestibility was obtained from the TJh30\% treatment and the lowest lipid digestibility was obtained from the unhydrolyzed corncob treatments, namely the $\mathrm{TJt} 15 \%$ and $\mathrm{TJ} 30 \%$. Furthermore, the highest energy digestibility was found on the TJh15\% and the lowest energy digestibility was found on the TJt30\% (Table 5). The ingredient digestibility analysis results showed a significant difference between unhydrolyzed and hydrolyzed corncob treatments. The highest ingredient digestibility was obtained from the TJh15\% treatment and the lowest ingredient digestibility was obtained from the $\mathrm{TJ} 15 \%$ treatment.

Table 6 presents the analysis results of digestive enzyme activity in red Nile tilapia. The amylase enzyme activity obtained a lower statistical value between the $\mathrm{TJt} 15 \%$ and $\mathrm{TJt} 30 \%$ treatments than the reference diet $(\mathrm{Rd})$ that obtained an insignificant different value between the TJh15\% and TJh $30 \%$ treatments. Based on the protease enzyme activity, the TJt15\%, TJt30\%, and TJh15\% treatments obtained a lower protease activity than the Rd, but showing a significant different level on the TJh30\% treatment. Moreover, the lipase activity value showed a lower value on the $\mathrm{TJ} 15 \%$, TJt30\%, and TJh30\% treatments than

Table 5. Digestibility value of the test diet using different hydrolyzed and unhydrolyzed corncob meal levels on red Nile tilapia

\begin{tabular}{ccccc}
\hline \multirow{2}{*}{ Digestibility (\%) } & \multicolumn{4}{c}{ Treatment } \\
\cline { 2 - 5 } & TJt15\% & TJt30\% & TJh15\% & TJh30\% \\
\hline Total & $59.98 \pm 0.15^{\mathrm{b}}$ & $54.78 \pm 1.29^{\mathrm{a}}$ & $65.83 \pm 0.86^{\mathrm{c}}$ & $59.55 \pm 0.68^{\mathrm{b}}$ \\
Protein & $87.29 \pm 0.93^{\mathrm{a}}$ & $87.02 \pm 1.48^{\mathrm{a}}$ & $91.28 \pm 1.78^{\mathrm{b}}$ & $90.76 \pm 1.21^{\mathrm{b}}$ \\
Lipid & $87.08 \pm 1.28^{\mathrm{a}}$ & $88.07 \pm 0.85^{\mathrm{a}}$ & $90.12 \pm 1.35^{\mathrm{b}}$ & $92.03 \pm 1.28^{\mathrm{c}}$ \\
Carbohydrate & $51.11 \pm 0.4^{\mathrm{b}}$ & $35.38 \pm 1.97^{\mathrm{a}}$ & $59.31 \pm 0.35^{\mathrm{c}}$ & $49.94 \pm 1.09^{\mathrm{b}} 73.48$ \\
Energy & $73.85 \pm 0.73^{\mathrm{b}}$ & $68.70 \pm 0.67^{\mathrm{a}}$ & $78.24 \pm 0.36^{\mathrm{c}}$ & $73.48 \pm 0.62^{\mathrm{b}}$ \\
Ingredient & $8.16 \pm 8.89^{\mathrm{a}}$ & $17.47 \pm 7.39^{\mathrm{a}}$ & $41.72 \pm 5.70^{\mathrm{b}}$ & $34.97 \pm 2.27^{\mathrm{b}}$ \\
\hline
\end{tabular}

Note: Different superscript letters after the average \pm standard error values on the same line show a significant difference $(\mathrm{P}<0.05)$. 
the Rd treatment, but the TJh15\% treatment was statisticallu higher than the Rd treatment.

The analysis results of blood plasme protein obtained a significant different value $(\mathrm{P}<0.05)$. The highest plasma protein value was obtained from the Rd treatment, which was insignificantly different from the TJh30\% treatment. The TJt15\% treatment was insignificantly different from the $\mathrm{TJh} 15 \%$ treatment, but was significantly different from all treatments. The lowest plasma protein value was obtained from the TJt30\% treatment (Table 6).

The glucose test on the 0-th hour showed a blood glucose level at $49.15 \mathrm{mg} / 100 \mathrm{ml}$ and the highest blood glucose level was found on the 2-nd hour after feeding the diets. The Rd diet treatment obtained the highest blood glucose level at $100.83 / 100 \mathrm{~mL}$.

The second and third highest blood glucose level was obtained from the TJh $30 \%$ and TJt15\% treatments at $86.43 \%$ and $82.19 \%$, respectively. Meanwhile, the lowest blood glucose level was obtained from the TJh15\% and TJt30\% treatments (74.39\% and $78.18 \%$, respectively). The fish blood glucose level in all treatments decreased on the 4-th to 6-th hour (Figure 1).

\section{Discussions}

The initial step study indicates that hydrochloric acid can decrease the crude fiber content of corncob meal. The hydrolysis success was found on the decreased crude fiber by $57.53 \%$ with 0.1 $\mathrm{N}$ concentration, 8-hour incubation, and 1:4 ratio. This condition means that different concentrations, incubation periods, and ingredient-solution ratios influence the hydrolysis success. Based on Lubis (2012), the hydrolysis product will increase along with the increased catalyst concentration until reaching a maximum point, and the hydrolysis reaction speed will become faster due to greater catalyst concentration.

The study results showed that the corncob meal hydrolyzed with $0.1 \mathrm{~N}$ hydrochloric acid, 8-hour incubation, and 1:4 ratio influenced the

Table 6. Digestive enzyme activity (IU/ml/minute), blood plasma protein (\%), and specific growth rate (\%) after feeding with the hydrolyzed and unhydrolyzed corncob diets

\begin{tabular}{cccccc}
\hline \multirow{2}{*}{ Parameter } & \multicolumn{5}{c}{ Treatment } \\
\cline { 2 - 6 } & $\mathrm{Rd}$ & TJt15\% & TJt30\% & TJh15\% & TJh30\% \\
\hline Amylase & $0.716 \pm 0,045^{\mathrm{b}}$ & $0.577 \pm 0.020^{\mathrm{a}}$ & $0.560 \pm 0.031^{\mathrm{a}}$ & $0.708 \pm 0.017^{\mathrm{b}}$ & $0.695 \pm 0.019^{\mathrm{b}}$ \\
Protease & $0.043 \pm 0.002^{\mathrm{c}}$ & $0.028 \pm 0.002^{\mathrm{a}}$ & $0.028 \pm 0.003^{\mathrm{a}}$ & $0.037 \pm 0.002^{\mathrm{b}}$ & $0.040 \pm 0.001^{\mathrm{bc}}$ \\
Lipase & $0.027 \pm 0.002^{\mathrm{b}}$ & $0.019 \pm 0.003^{\mathrm{a}}$ & $0.018 \pm 0.005^{\mathrm{a}}$ & $0.032 \pm 0.002^{\mathrm{c}}$ & $0.021 \pm 0.002^{\mathrm{a}}$ \\
$\begin{array}{c}\text { Blood plasma } \\
\text { protein }\end{array}$ & $7.49 \pm 0.20^{\mathrm{a}}$ & $6.41 \pm 0.31^{\mathrm{b}}$ & $5.68 \pm 0.41^{\mathrm{c}}$ & $6.83 \pm 0.49^{\mathrm{d}}$ & $7.5 \pm 0.27^{\mathrm{ad}}$ \\
SGR & $2.43 \pm 0.07^{\mathrm{d}}$ & $1.77 \pm 0.04^{\mathrm{b}}$ & $1.38 \pm 0.02^{\mathrm{a}}$ & $2.00 \pm 0.10^{\mathrm{c}}$ & $1.74 \pm 0.06^{\mathrm{b}}$ \\
\hline
\end{tabular}

Note: $\mathrm{Rd}=$ Reference diet; TJt = Unhydrolyzed corncob; TJh = Hydrolyzed corncob; SGR = Specific growth rate. Different superscript letters after the average \pm standard deviation values on the same line show a significant difference $(\mathrm{P}<0.05)$.

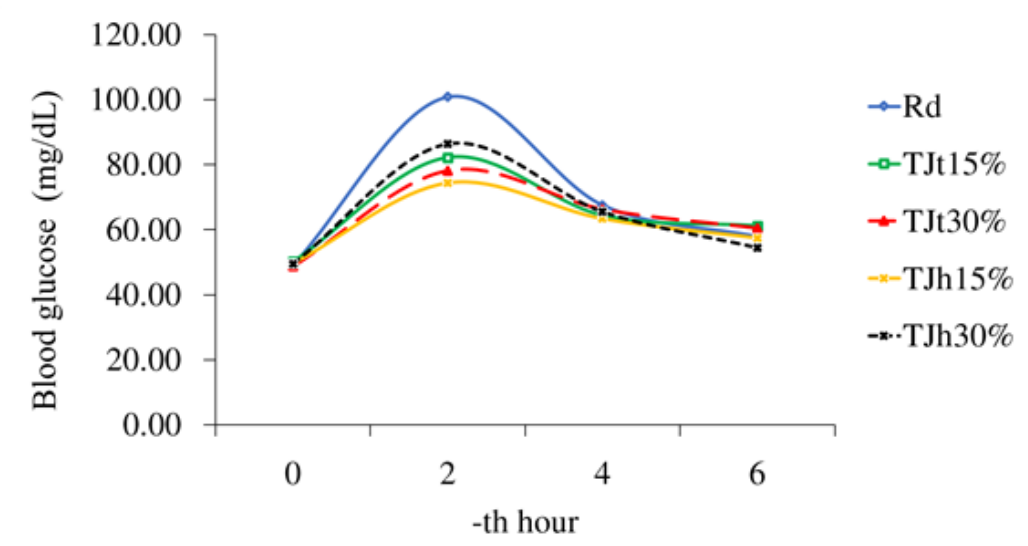

Figure 1. Blood glucose on the 0-th to 6-th hour $(\mathrm{mg} / 100 \mathrm{~mL})$ in red Nile tilapia after feeding with the hydrolyzed and unhydrolyzed corncob meal diet. 
crude fiber fraction contents as showing decreased crude fiber fractions, such as NDF, ADF, and hemicellulose at $38.15 \%, 6.43 \%$, and $61.92 \%$, respectively. This condition was thought as the acidic hydrolysis could degrade the complex fiber fraction chain into a simpler form either NDF, ADF, or hemicellulose. These results were similar to the previous studies reported by Santoso et al. (2017) and Sumiana et al. (2020) as the hydrolysis process could degrade the crude fiber fraction in feed ingredients. The high fiber fraction content of NDF and ADF in the animal feed can decrease its digestibility value (Cindy et al., 2020; Febriany et al., 2020). The lowest digestibility values were obtained from the $\mathrm{TJ} 30 \%$ treatment, namely the total, carbohydrate, and energy digestibility values. For ingredient digestibility, the highest value was obtained from the TJt15\% treatment. This condition was thought of as the increased corncob use that increased the fiber fraction and decreased the diet digestibility value.

The total, carbohydrate, energy, and ingredient digestibility values in hydrolyzed corncob treatments were higher than in unhydrolyzed corncob treatments. This condition was thought due to simpler molecules contained in hydrolyzed ingredient than unhydrolyzed ingredient. Previous study results showed that the hydrolyzed ingredient obtained a higher digestibility value than the unhydrolyzed ingredient either in the total, carbohydrate, energy, and ingredient digestibility values (Anugrah, 2018; Sumiana et al., 2020). A similar condition was also reported by Suprayudi et al. (2012) in striped catfish, Suprayudi et al. (2014) in common carp, and Suprayudi et al. (2016) in Nile tilapia. Based on the digestibility test results, the hydrolyzed ingredient could increase the total, nutrient (protein, lipid, and carbohydrate), energy, and ingredient digestibility values, but the digestibility values decreased when the ingredient percentage was 30\%. Palupi (2017) reported that the use of poultry by-product meal (PBM) in Nile tilapia by $30 \%$ could decrease the total digestibility value. A similar condition was also found in L. vannamei (De Carvalho et al., 2016). The higher the corncob use, the higher crude fiber content in the diet, resulting in the more decreased diet quality.

The analysis results of digestive enzyme activities showed a significant influence $(\mathrm{P}<0.05)$ on amylase, protease, and lipase enzymes. The lowest enzyme activity values either amylase, protease, or lipase was obtained from the unhydrolyzed corncob diet treatment. This condition was thought due to high crude fiber content in diet. High amylase enzyme in the Rd and hydrolyzed diet treatments may be caused by better carbohydrate quality and percentage than in unhydrolyzed diet treatments on each red Nile tilapia sample $(0.716 \pm 0.045 ; 0.708 \pm 0.017$; $0.695 \pm 0.019)$. The amylase enzyme activity in Nile tilapia will increase along with the increased starch content in the diet (Fitriliyani, 2011). A similar condition was also found in Trachinotus ovatus, Larmichthys crocea dan Plectropomus leopardu (Zhou et al., 2015; Zhou et al., 2016; Xia et al., 2019). Meanwhile, the lowest lipase enzyme activity was obtained from the TJt15\%, $\mathrm{TJ} 30 \%$, and $\mathrm{TJh} 30 \%$ treatments. Lipase enzyme has a function to hydrolyze triglycerides to fatty acids and monoglycerides which can be absorbed.

Based on the glucose test results, the highest glucose utilization level was occurred on the 2 -nd hour and decreased on the 4-th to 6-th hour. This condition showed that the Nile tilapia had a good capability in utilizing the carbohydrates such as glucose as an energy source. These study results followed Sumiana et al. (2020) and Ren etal.(2015) in Nile tilapia and Megalobrama amblycephala. The glucose absorption decreased on the 4-th to 6-th hours. Based on Shiau and Chuang (1995), the plasma glucose in Nile tilapia returned to the basal metabolism state after 6-hour feeding. The blood plasma protein measurement was aimed to identify the nutrient (protein) absorption level of diets. Low blood plasma protein levels in TJt15\% and $\mathrm{TJ} 30 \%$ were thought due to low protein digestibility value the contrary of the hydrolyzed corncob diet treatments. Similar studies were found in Yones \& Metwalli (2015), Suprayudi et al. (2016), and Palupi (2017).

\section{CONCLUSION}

A corncob hydrolysis with $0.1 \mathrm{~N} \mathrm{HCl}$, 8-hour incubation, and 1:4 ratio could decrease the crude fiber, NDF, ADF, hemicellulose, followed by the increased digestibility and utilization of corncob in diets as a carbohydrate source for red Nile tilapia.

\section{REFERENCES}

[AOAC] Association of Official Analytical Chemists. 2012. Official Methods of Analysis of AOAC Intl. 19th ed. Maryland (US): Association of Official Analytical Chemists.

Amarwati H, Subandiyono, Pinandoyo. 2015. 
Pemanfaatan tepung daun singkong Manihot utilissima yang difermentasi dalam pakan buatan terhadap pertumbuhan benih ikan nila merah Oreochromis niloticus. Journal of Aquaculture Management and Technology 4: 51-59.

Amin M, Taqwa FH, Yulisman, Mukti RC, Rarassari MA, Antika RA. 2020. The effectiveness of utilization of local raw materials as feed to increase productivity of catfish Clarias sp. in Sakatiga village, Indralaya District, Ogan Ilir Regency, South Sumatra. Journal of Aquaculture and Fish Health 9: 222-231.

Anugrah. 2018. Kecernaan dan aktivitas enzim ikan nila Oreochromis sp. yang diberi biji karet hevea brasiliensis dihidrolisis dengan crude enzim rumen domba dan koktail enzim. [Tesis]. Bogor. Institut Pertanian Bogor.

Boonanuntanasarn S, Kumkhong S, Yoohat K, Juana EP, Burela C, Marandela L, Panserata S. 2018. Molecular responses of Nile tilapia Oreochromis niloticus to different levels of dietary carbohydrates. Aquaculture 482: $177-$ 123.

Borlongan TG. 1990. Studies on the lipases of milkfish Chanos chanos. Aquaculture 89: 315-325.

De Carlvalho RAPLF, Ota RH, Kadry VO, Takon AGJ, Lemos D. 2016. Apparent digestibility of protein, energy and amino acids of six protein sources included at three levels in diets for juvenile white shrimp Litopenaeus vannamei reared in high performance conditions. Aquaculture 465: 223-234.

Dubowski KM. 2008. An o-toluidine method for body-fluid glucose determination. Clinical Chemistry 54: 1919-1920.

Cindy PR, Tuturoong RAV, Pendong AF, Waani MR. 2020. Kecernaan NDF dan ADF pakan lengkap berbasis tebon jagung pada sapi FH. Zootec 40: 542-551

Coutinho JJDO, Neira LM, Sandre LCGd, Costa JId, Martins MIEG, Portella MC, Carneiro DJ. 2018. Carbohydrate-to-lipid ratio in extruded diets for Nile tilapia farmed in net cages. Aquaculture 497: 520-525.

Enami HR. 2011. A review of using canola/ rapeseed meal in aquaculture feeding. Journal of Fisheries and Aquatic Science 6: 22-36.

Febriany FW, Abraham FP, Kaunang CL, Waani MR. 2020. Kecernaan NDF dan ADF ransum komplit berbasis tebon jagung pada sapi peranakan ongole. Zootec 40: 522-530.
Fitriliyani I. 2011. Aktifitas enzim saluran pencernaan ikan nila Oreohromis niloticus dengan pakan mengandung tepung daun lamtoro Leucaena leucophala terhidrolisis dan tanpa hidrolisis dengan ekstrak enzim cairan rumen domba. BIOSCIENTIAE 8: 16-31.

Haidar MN, Petie M, Heinsbroek LTN, Verreth JAJ, Schrama JW. 2016. The effect of type of carbohydrate (starch vs nonstarch polysaccharides) on nutrients digestibility, energy retention and maintenance requirements in Nile Tilapia. Aquaculture 463: 241-247.

Jusadi D, Ekasari J, Kurniansyah A. 2013. Improvement of cocoa-pod husk using sheep rumen liquor for tilapia diet. Jurnal Akuakultur Indonesia 12: 40-47.

Kamalam BS, Medale F, Panserat S. 2017. Utilisation of dietary carbohydrates in farmed fishes: new insights on influencing factors, biological limitations and future strategies. Aquaculture 467: 3-27.

Kanengoni AT, Chimonyo M, Ndimba BK, Dzama K. 2015. Potential of using maize cobs In pig diets - A Review. Asian-Australasian Journal of Animal Sciences 12: 1669-1679.

Klahan R, Yotha P, Montree P. 2016. Utilization of corncob as feedstuff on growth performance, feed utilization and carcass composition of Nile tilapia Oreochromis niloticus L.. International Journal of Environmental and Rural Development 7-2.

Lubis MR. 2012. Hidrolisis pati sukun degan katalisator $\mathrm{H}_{2} \mathrm{SO}_{4}$ untuk pembuatan perekat. Jurnal Rekayasa Kimia dan Lingkungan 9: 62-67.

Muliani, Khalil M, Murniati, Rusydi R, Ezraneti R. 2019. Nutrition content analysis of different pellet feeds from different vegetable raw material to nutritional success of herbivorous fish. Acta Aquatica: Aquatic Sciences Journal 6: 86-92.

Olagunju A, Onyike E, Muhammad A, Aliyu S and. Abdullahi AS. 2013. Effects of fungal Lachnocladium spp. pretreatment on nutrient and antinutrient composition of corn cobs. African Journal of Biochemistry Research 7: 210-214.

Palupi ET. 2017. Kinerja pertumbuhan dan biokimia darah ikan nila Oreochromis niloticus yang diberi pakan mengandung poultry byproduct meal. [Tesis]. Bogor. Institut Pertanian Bogor.

Pointner M, Kuttner P, Obrlik T, Jäger A, Kahr H. 2014. Composition of corncobs as a substrate 
for fermentation of biofuels. Agronomy Research 1: 391-396.

Purwanti A. 2013. Optimasi kondisi proses pengambilan asam alginat dari alga coklat. Jurnal Teknologi Technoscientia 5: 125-133.

Ren M, Tsion HMH, Xie J, Liu B, Zhou Q, Ge X, Pan L, Chen R. 2015. Effects of dietary carbohydrate source on growth performance, diet digestibility and liver glucose enzyme activity in blunt snout bream Megalobrama amblycephala. Aquaculture 438: 75-81.

Rostika R, Safitri R. 2012. Influence of fish feed containing corn-cob was fermented by Trichoderma sp., Aspergillus sp., Rhizopus oligosporus to the rate of growth of Java barb Puntius gonionitus. APCBEE Procedia 2: 148-152.

Santoso B, Widayati TW, Hariadi BT. 2017. Nutritive value in vitro fermentation characteristics and nutrient digestibility of agro-industrial byproducts-based complete feed block enriched with mixed microbes Pakistan Journal of Nutrition 16: 470-476.

Shiau SY, Chuang JC. 1995. Utilization of disaccharides by juvenile tilapia Oreochromis niloticus $\times$ O. aureus. Aquaculture 133: 249256.

Sumiana IK, Ekasari J, Jusadi D, Setiawati M. 2020. Utilization of fermented sago pulp as source of carbohydrat in feed for Nile tilapia Oreochromis niloticus. Jurnal Akuakultur Indonesia 19: 106-117.

Suprayudi MA. 2017. Bahan pakan lokal berbasis hasil samping agroindustri pertanian [Pajale da Sawit]. Bogor. Orasi Guru Besar IPB.

Suprayudi MA, Alim S, Fauzi IA, Ekasari J, Setiawati M, Junior MZ, Tacon AGJ. 2016. Evaluation of hydrolysed rubber seed meal as a dietary protein source for Nile tilapia L. Aquaculture Research 2016: 1-8.

Suprayudi MA, Irawan WS, Utomo NBP. 2014. Evaluation of incubated defatted rubber seed meal with sheep rumen liquor for Pangasius diet. Jurnal Akuakultur Indonesia 13: 146151.
Suprayudi MA, Edriani G, Ekasari J. 2012. Evaluasi kualitas produk fermentasi berbagai bahan baku hasil samping agroindustri lokal: Pengaruhnya terhadap kecernaan serta kinerja pertumbuhan ikan mas. Jurnal Akuakultur Indonesia 11: 1-5.

Watanabe T. 1988. Fish nutrition and mariculture. Tokyo (JP) : Departement of Aquatic Bioscience. Tokyo University of Fisheries. JICA.

Widaningsih N, Dharmawati S, Puspitasari N. 2018. Crude protein and crude fiber content of corn cob fermentated use different rumen fluid levels. ZIRAA'AH 43: 255-265.

Xia S, Sun J, Li M, Zhao W, Zhang D, You H, Rajkumar M, Wu B. 2019. Influence of dietary protein level on growth performance, digestibility and activity of immunityrelated enzymes of leopard coral grouper, Plectropomus leopardus (Lacépède, 1802). Aquaculture Nutrition 2019 00: 1-6.

Yones AMM, Metwalli AA. 2015. Effects of fish meal substitution with poultry by-product meal on growth performance, nutrients utilization and blood contents of juvenile Nile tilapia Oreochromis niloticus. Journal of Aquaculture 7: 1 .

Zhou P, Wang M, Xie F, Deng DF, Zhou Q. 2016. Effects of dietary carbohydrate to lipid ratios on growth performance, digestive enzyme and hepatic carbohydrate metabolic enzyme activities of large yellow croaker Larmichthys crocea. Aquaculture 452: 45-51.

Zhou C, Ge X, Niu J, Li H. 2015. Effect of dietary carbohydrate levels on growth performance, body composition, intestinal and hepatic enzyme activities, and growth hormone gene expression of juvenile golden pompano, Trachinotus ovatus. Aquaculture 437: 390397.

Zuraida, Jusadi D, Utomo NBP. 2013. Efektivitas penambahan enzim cairan rumen domba terhadap penurunan serat kasar bungkil kelapa sebagai bahan baku pakan ikan. Jurnal Akuakultur Rawa Indonesia $1: 117-126$. 